\title{
Effects of Volunteering Experiences and Motivations on Attitudes Toward Prisoners: Evidence from Hong Kong
}

\author{
Wing Hong Chui • Kevin Kwok-yin Cheng
}

Received: 28 March 2012 / Accepted: 2 July 2012 / Published online: 1 August 2012

(C) The Author(s) 2012. This article is published with open access at Springerlink.com

\begin{abstract}
Volunteers are playing an increasingly bigger role in correctional institutions both in Western settings and in the Hong Kong Chinese context, and yet previous studies have focused only on descriptive accounts of their motivation and satisfaction. Utilizing three samples in Hong Kong, namely prison volunteers $(N=54)$, non-prison volunteers $(N=146)$, and non-volunteers $(N=77)$, the present study compares these groups' attitudes toward prisoners. Moreover, this study examines the correlations between volunteer satisfaction and volunteer motivation and attitudes toward prisoners. The results indicate that, compared to the non-volunteer group, both the volunteer groups exhibited more positive attitudes toward prisoners. For the prison volunteers, motivation to express important values and to help others correlated with the attitude that prisoners can change positively. The implications of the study are discussed.
\end{abstract}

Keywords Prison volunteers · Volunteer satisfaction · Volunteer motivation · Attitudes toward prisoners $\cdot$ Hong Kong Chinese sample

\section{Introduction}

With an emphasis on rehabilitation and reintegration, correctional institutions are resorting increasingly to prison volunteers to provide services to inmates ranging from emotional support to educational seminars. Various non-governmental organizations (NGOs) have volunteered to work with the Hong Kong Correctional Services Department (CSD) to provide different services and activities for prisoners. In 2004, the CSD Rehabilitation Volunteer Group was set up to support the CSD in offering programs such as language courses and computer training for inmates (Hong Kong Correctional Services 2010a). Despite the large role that prison volunteers play in correctional institutions, there have been only a few studies on this unique group of people in Western settings, and even less attention has been paid to them in the Chinese context. The extant literature focuses mainly

W. H. Chui $(\bowtie) \cdot$ K. K.-y. Cheng

Department of Social Work and Social Administration, University of Hong Kong, Pokfulam, Hong Kong SAR

e-mail: ericchui@hku.hk 
on descriptive accounts of the motivations, work, and satisfactions of prison volunteers only (Chui and Cheng 2012; Kerley et al. 2009; Tewksbury and Collins 2005; Tewksbury and Dabney 2004). The present study goes beyond the existing research to determine whether volunteering experiences, measured in terms of time spent volunteering in prisons and volunteer satisfaction, and volunteer motivations, impact volunteers' attitudes toward prisoners.

The results will have policy implications as the attitudes of those who come into frequent contact with prisoners could either promote or impede their rehabilitation (Melvin et al. 1985). The attitudes of prison volunteers, a group that is playing an increasingly larger role within prisons, have never been measured. Past studies have shown that feelings of prejudice and discrimination could hinder prisoners' rehabilitation and reintegration process while increasing their chances of recidivism (Henry and Jacobs 2007; Maxwell and Mallon 1997; Potuto 1980; Uggen et al. 2004). Encouraging volunteering with prisoners could be a way to advance intergroup contact and cultivate positive attitudes toward offenders (Allport 1954; Pettigrew and Tropp 2000; Sheriff 1966). At the same time, however, the volunteer work that is done could be viewed as a form of unwarranted religious proselytizing as many prison volunteers are driven by their religious beliefs (Tewksbury and Dabney 2004).

By measuring the volunteering satisfaction and motivation of a sample of prison volunteers in Hong Kong together with their attitudes toward prisoners, this study tests whether prison volunteering experiences and motivations could indeed influence volunteers' perceptions of inmates. In other words, are positive attitudes that prisoners can change for the better affected by volunteers' satisfaction or motivation in pursuing a personal agenda? The results will increase our insight into the underlying motivations of prison volunteers. This study also replicates past research that has compared attitudes toward prisoners among different professions such as law enforcement staff and correctional staff, and the public by studying three groups (prison volunteers, non-prison volunteers, and non-volunteers) to provide a comparative insight into the relationship between volunteers and their attitudes toward prisoners.

\section{Overview of Hong Kong Correctional Services}

In Hong Kong, the CSD operates 29 correctional institutions plus three half-way houses, four rehabilitation centers and two custodial wards in public hospitals. The total inmate population stands at slightly over 9,000 at the end of 2011. There is an emphasis on discipline and rehabilitation in these facilities (Chui 2005; Laidler 2009). Prisoners are assigned an assortment of tasks that are thought to offer them training that will eventually lead to their successful reintegration in society. These tasks include manufacturing work, such as the production of office furniture, uniforms, and traffic signs, and laundry work for other government departments such as hospitals and the fire department (Hong Kong Correctional Services 2010b; Laidler 2009). Prison volunteers are increasingly responsible for providing many services for inmates and assisting them in their training; for example, prison volunteers hold tutor and hobby classes for inmates to further their education. The aforementioned CSD Rehabilitation Volunteer Group works closely with the CSD to offer training courses and other cultural activities, such as tai chi and calligraphy, to prisoners (Hong Kong Correctional Services 2010c).

The CSD Rehabilitation Volunteer Group is made up mainly of teachers, social workers, retirees, and university students (Hong Kong Correctional Services 2010c). The Commissioner of the CSD can also issue prison visitor passes to those "interested in the welfare, reform and after-care of prisoners" [s.236(1) Prison Rules Cap. 234A]. Similarly, a full-time prison chaplain arranges spiritual activities with the aid of other voluntary prison chaplains 
and religious workers. Moreover, the CSD currently works with over 80 NGOs to assist in the rehabilitation of offenders (Hong Kong Correctional 2010b). However, evaluations of Hong Kong prisons have shown an overcrowding problem that affects directly the meaningfulness of inmates' activities regarded as useful to the reintegration process and leading to a reduction in recidivism. In order to keep the numerous inmates occupied, they are asked to perform activities such as cotton and envelope making, tasks that are considered to offer little in terms of skills training (Human Rights Watch and the Hong Kong Human Rights Monitor 1997).

\section{Literature Review}

The focus of the extant literature on prison volunteers has been mainly on descriptive accounts of the activities that volunteers perform in prison and their motivations for volunteering. One of the first works to systematically profile prison volunteers was conducted by Tewksbury and Dabney (2004), who surveyed a sample of 72 volunteers in the United States. Their sample was made up predominately of Caucasian educated males who were not actively recruited but rather chose to volunteer in prisons because they believed that their volunteer work could make a difference to the lives of inmates. Most of these prison volunteers participated in religious programs for prisoners and were satisfied with both their experiences and the correctional institution (a medium-security prison in the United States) where they did their volunteer work.

Following this initial work, Tewksbury and Collins (2005) focused exclusively on religious workers by surveying 41 prison chapel volunteers. Their study revealed that these religious volunteers engaged primarily in activities for inmates that were religious in nature. The majority of those surveyed were involved with preaching to inmates and counseling on spiritual issues as opposed to more secular duties such as providing counseling on inmates' personal difficulties or simply befriending inmates. Interestingly, the role played by religious volunteers is distinct from that of prison chaplains - the people responsible for managing the activities of chapel volunteers. Studies have shown that prison chaplains themselves engage in a mixture of spiritual and secular programs (Sundt and Cullen 1998; Sundt et al. 2002). The majority of prison volunteers in Tewksbury and Collins' (2005) study reported that they were motivated to volunteer because they felt that they were doing God's work. What is concerning is that these prison volunteers also noted that they had received little training to prepare them for their work in prisons.

A comparable situation was found in Hong Kong prisons in a recent study. From interviews conducted with both Christian prison chaplains and Buddhist volunteers, Chui and Cheng (2011) concluded that Christian prison chaplains perform a wide range of activities in correctional institutions, ranging from counseling to hosting skill training courses, whereas Buddhist volunteers concentrate on developing interpersonal relationships with inmates and teaching them about their beliefs through one-on-one conversations. The reason for the different approaches is that prison chaplains are given more autonomy and more responsibilities inside prisons. Under the Prison Ordinance (Cap. 234), prison chaplains are given chaplain passes that grant them easier access inside correctional institutions. Volunteers of other faiths are more restricted in their visits and are issued only visitor passes. Here, it appears that certain faiths are treated more favorably and given greater opportunities to provide services or even conduct proselytizing work.

A lot of the social work literature points to the ethical issues that arise when NGOs and social workers pursue religious proselytizing when providing services for client groups (Jayasinghe 2007; Sherr et al. 2009; Spano 2007). Proselytizing refers to attempts and 
efforts to convert people to a certain religious faith. The worry is that social workers, or even volunteers, occupy a position of power and may use the opportunities afforded to them to engage in unwelcome religious discussions or attempts at conversion. With regard to prison volunteers, sharing their spiritual beliefs with inmates has been cited as a prime motivating factor for their prison volunteer work (Chui and Cheng 2012; Kerley et al. 2009; Tewksbury and Collins 2005; Tewksbury and Dabney 2004).

Jayasinghe (2007) outlined several ethical issues that arise when faith-based NGOs conduct proselytizing work alongside the provision of humanitarian aid that can be applicable to prison volunteering. First, when choosing a community to assist, certain groups may be denied assistance because they are deemed to offer fewer opportunities to proselytize. Second, proselytizing may cause religious doubts and reduced spiritual well-being. Third, NGOs may engage in proselytizing work without the consent of the clients and effectively exploit their vulnerabilities. Lastly, governments may face the ethical dilemma of denying certain NGOs opportunities to provide services because of their proselytizing work or forcing them to offer assistance only without any proselytizing.

Such ethical dilemmas for NGOs are illustrated by Sherr et al.'s (2009) case study of one Christian agency that matched needy clients with a support group called a 'spiritual family' that aimed to change people's lives through a Christian perspective. Registered social workers were responsible for the selection and matching process. The authors found that, despite efforts by the social workers to be candid up front about the religious nature of the program, potential clients were inclined to frame their responses in ways that would increase their odds of being accepted on to the program. In addition, even after successfully gaining entry to the program, clients expressed that they felt that they had to go along with religious discussions during the group meetings and that they were compelled to belong to a religious congregation. The religious workers admitted that the program was regarded as an opportunity to evangelize to non-Christians. A drawback of this study is that it based its conclusions on a single case study of one non-profit organization.

On a broader level, in a survey of registered social workers, Canda et al. (2004) found that social workers were generally supportive of incorporating spirituality oriented activities in their works, including referrals to clergies and utilizing prayer and meditation. Indeed, studies have increasingly placed an emphasis on the need for social workers to include the promotion of religion and spirituality in their practice (Gilbert 2000; Gilligan and Furness 2006; Hodge 2005). At the same time, practitioners have reported a need to ensure that the sharing of one's religious beliefs with clients does not lead to proselytizing (Sheridanet al. 1994), and past scholarship has highlighted guidelines for practitioners to include spiritual activities in their services in an ethical manner (Jayasinghe 2007; Sherr et al. 2009; Spano 2007).

Similarly, in recent years, there has been a resurgence in the promotion of religious programs in prisons (Sundt et al. 2002) and the use of religion to help prisoners adjust to life after prison (McRoberts 2002). Governments are turning to religious organizations to assist prisoners and ex-prisoners because, since most religious organizations do not charge for their services and employ large number of volunteers, they are a cost-efficient alternative (Sundt et al. 2002; Worthington et al. 1996). Given (1) how the vast majority of prison volunteers are motivated to share their faith with inmates (e.g., Kerley et al. 2009), and (2) the lack of training that is provided to volunteers prior to commencing their work (Tewksbury and Collins 2005), the work and motivations of prison volunteers deserve greater scrutiny.

While the extant literature provides valuable insights into what prison volunteers do, as yet there has been no measurement of the potential impact of their volunteering experiences on their views about those they serve. The existing research on attitudes toward prisoners has focused mainly on gender and on differences in attitudes between professions, in particular 
rehabilitation teams, law enforcement officers, correction officers, and the public (Horn and Hollin 1997; Kjelsberg et al. 2007; Melvin et al. 1985; Murphy and Brown 2000; Na and Lofius 1998; Ortet-Fabregat et al. 1993). Research has shown that police officers (Horn and Hollin 1997) and correction officers (Kjelsberg et al. 2007; Ortet-Fabregat et al. 1993) have the least favorable attitudes toward prisoners, whereas, as would be expected, those whose work relates to rehabilitation exhibit the most positive attitudes toward prisoners (Melvin et al. 1985; Ortet-Fabregat et al. 1993). Given the substantial role of prison volunteers within correctional institutions, it is somewhat surprising that their attitudes toward prisoners have never been measured.

Some evidence of this relationship was found by Kerce et al.'s (1994) study of navy correction officers' job satisfaction and attitudes toward confinees (navy officers detained in correctional institutions). In this study, navy officers who reported higher ratings of overall job satisfaction had a more treatment-oriented approach and a belief that confinees could be retrained for service and displayed more positive attitudes toward them. To go beyond a comparison of attitudes toward prisoners between prison volunteers and other groups, the present study seeks to determine whether volunteer experiences and motivations impact perceptions.

\section{Methodology}

\section{Sample}

Over a 3-month period in 2010, a total of 277 participants were recruited for this study with the assistance of three NGOs, one of which specifically organizes prison volunteering. A sample of college students also participated in the study. The participants were classified into three groups according to their volunteering experience. The first group consisted of 54 prison volunteers who had had some experience of working with prisoners in the previous 12 months ("prison volunteers"). The second group consisted of 146 volunteers who had had experience of volunteering with target groups other than prisoners in the previous 12 months ("non-prison volunteers"). Lastly, the third group consisted of 77 participants who had had no experience of any volunteering activities in the previous 12 months ("non-volunteers").

The demographic characteristics of the participants in terms of gender, age, highest education level, marital status, and religious belief, are presented in Table 1. Most of the participants were female and were educated; all indicated that they had at least a secondary (or high school) level education. Most of the participants reported that they were single. In terms of age, the prisoner volunteer group was the eldest $(M=32.9 ; \mathrm{SD}=11.3)$, followed by the non-prisoner volunteer group $(M=28.0 ; \mathrm{SD}=8.0)$ with the youngest being the nonvolunteer group $(M=22.1 ; \mathrm{SD}=4.6)$. Like the Western samples in past studies, most of the prison volunteers in our sample identified themselves as Christians $(N=44)$, as did most of the non-prisoner volunteers $(N=81)$, whereas in the non-volunteer group, most $(N=46)$ reported that they had no religious beliefs. All of the participants were Chinese.

\section{Measures}

\section{Attitudes Toward Prisoners Scale}

The Attitudes Toward Prisoners (ATP) scale was developed by Melvin et al. (1985) to measure people's attitudes toward prisoners, and it has been a popular tool for researchers. 
Table 1 Demographic characteristics of the participants ${ }^{\mathrm{a}}$

${ }^{\text {a }}$ Some numbers do not add up to the total because of missing data

\begin{tabular}{|c|c|c|c|}
\hline & $\begin{array}{l}\text { Prison } \\
\text { volunteers } \\
(N=54)\end{array}$ & $\begin{array}{l}\text { Non-prison } \\
\text { volunteers } \\
(N=146)\end{array}$ & $\begin{array}{l}\text { Non-volunteers } \\
(N=77)\end{array}$ \\
\hline \multicolumn{4}{|l|}{ Gender } \\
\hline Male & $22.2 \%$ & $42.5 \%$ & $20.7 \%$ \\
\hline Female & $77.8 \%$ & $57.5 \%$ & $79.2 \%$ \\
\hline Age (mean) & 32.9 & 28.0 & 22.1 \\
\hline \multicolumn{4}{|l|}{ Education } \\
\hline Secondary & $18.5 \%$ & $10.9 \%$ & $15.6 \%$ \\
\hline Tertiary and above & $79.6 \%$ & $88.4 \%$ & $81.8 \%$ \\
\hline \multicolumn{4}{|l|}{ Marital status } \\
\hline Single & $64.8 \%$ & $78.8 \%$ & $96.1 \%$ \\
\hline Married & $29.6 \%$ & $16.4 \%$ & $0.04 \%$ \\
\hline Separated/divorced & $0.1 \%$ & $0.02 \%$ & $0 \%$ \\
\hline Cohabitation & $0 \%$ & $0.01 \%$ & $0 \%$ \\
\hline \multicolumn{4}{|l|}{ Religion } \\
\hline Christian & $81.5 \%$ & $55.5 \%$ & $35.1 \%$ \\
\hline Buddhist & $0.02 \%$ & $0.04 \%$ & $0.03 \%$ \\
\hline Other & $0 \%$ & $0.02 \%$ & $0.03 \%$ \\
\hline None & $16.7 \%$ & $37.0 \%$ & $59.7 \%$ \\
\hline
\end{tabular}

The scale consists of 36 items and includes both positively (e.g., "Most prisoners are victims of circumstance and deserve to be helped") and negatively (e.g., "Trying to rehabilitate prisoners is a waste of time and money") worded items. Responses are made on a 5-point Likert scale ranging from 1 (strongly disagree) to 5 (strongly agree). A higher score (after the negatively worded items are reversed) indicates a more positive attitude toward prisoners and a belief that prisoners are capable of positive change and not so different from normal individuals, whereas a lower score indicates a more negative attitude toward prisoners and agreement with the idea that prisoners are deviants who are incapable of positive change.

\section{Volunteer Satisfaction Index}

The Volunteer Satisfaction Index (VSI) was developed originally by Galindo-Kuhn and Guzley (2001) to measure volunteers' satisfaction with different aspects of their volunteering experience. The scale consists of 24 items with responses made on a 7-point Likert scale ranging from 1 (strongly dissatisfied) to 7 (strongly satisfied). A Chinese version of the VSI was recently validated in a Chinese context using a sample of university students in Hong Kong (Wong et al. 2011). Three dimensions of volunteer satisfaction were derived. The first, relationship within organization, measures the satisfaction gained from interacting with the staff in the volunteering organization (i.e., "The flow of communication coming to me from paid staff and board members"). The second, personal gain, measures the feelings of one's autonomy and individual growth gained through the volunteering experience (i.e., "The chance I have to utilize my knowledge and skills in my volunteer work"). Finally, relationship with peers, which measures the satisfaction gained from the forming of relationships with fellow volunteers (i.e., "The amount of interaction I have with other volunteers in the organization"). A higher score indicates a greater degree of satisfaction with the volunteering experience. 


\section{Volunteer Functions Inventory}

The Volunteer Functions Inventory (VFI) was developed by Clary et al. (1998) to measure the underlying motivations behind a person's decision to volunteer. The scale consists of 30 items on a 7-point Likert scale ranging from 1 (strongly disagree) to 7 (strongly agree). A Chinese version of the VFI was validated recently using a sample of university students in Hong Kong (Wu et al. 2009). Six functions were identified that would potentially be served by volunteerism. The first, values, measures the opportunities that volunteering may provide to an individual to express values that relate to helping others (e.g., "I can do something for a cause that is important to me"). The second function, understanding, measures the opportunities that allow the volunteer to gain new learning experiences (e.g., "Volunteering allows me to gain a new perspective on things"). The third function, enhancement, measures the opportunities that volunteering can provide to promote the psychological growth of the volunteer (e.g., "Volunteering makes me feel better about myself"). The fourth function, career, measures the opportunities afforded by volunteering to promote career aspirations (e.g., "I can make new contacts that might help my business or career"). The fifth function, social, measures how volunteering enhances the volunteer's social relationships (e.g., "Volunteering is an important activity to the people I know best"). The sixth function, protective, measures how volunteering helps to reduce the volunteer's negative feelings such as guilt (e.g., "Doing volunteer work relieves me of some of the guilt over being more fortunate than others"). For each function, a higher score indicates a greater motivation to volunteer because of that function.

\section{Length of Volunteering Experiences}

In addition to the demographic characteristics described above, the questionnaire asked participants to indicate the target groups of their volunteering experiences and the length of their volunteering work measured in months.

\section{Results}

As might be expected, the prison volunteer group displayed the most positive attitude toward prisoners, followed by the non-prison volunteer group, with the non-volunteer group being the least positive. The mean ATP scores and standard deviations of each group are presented in Table 2. In order to determine whether there are statistically significant group differences amongst the three participant groups with respect to their attitudes toward prisoners, a oneway analysis of variance (ANOVA) was performed. It was found that there were indeed significant group differences between the three groups in terms of their perceptions of prisoners $[F(2,273)=17.57, p<0.001)]$ A post-hoc Tukey analysis found that there were significant differences between the non-volunteer group and the non-prison volunteer group $(p<0.001)$ as well as between the non-volunteer group and the prison volunteer group $(p<0.001)$. However, no significant differences were found between the two volunteer groups. A possible reason for

Table 2 Mean Attitudes Toward Prisoners (ATP) scores and standard deviations of the three groups

\begin{tabular}{lll}
\hline & Mean & SD \\
\hline Prisoner volunteers & 133.74 & 11.50 \\
Non-prisoner volunteers & 129.55 & 12.75 \\
Non-volunteers & 120.80 & 14.86 \\
\hline
\end{tabular}


Table 3 Mean Volunteer Satisfaction Index (VSI) and Volunteer Functions Inventory (VFI) scores and standard deviations of prison volunteers $(N=54)$

\begin{tabular}{lcc}
\hline & Mean & SD \\
\hline VSI & & \\
Relationship with organization & 4.86 & 1.04 \\
Personal gain & 5.18 & 0.72 \\
Relationship with peers & 5.22 & 0.84 \\
VFI & & \\
Values & 5.40 & 0.69 \\
Understanding & 5.14 & 0.77 \\
Enhancement & 4.52 & 1.02 \\
Career & 3.66 & 1.32 \\
Social & 3.69 & 1.32 \\
Protective & 3.67 & 1.05 \\
\hline
\end{tabular}

this is likely to be that those who choose to volunteer and assist others without monetary reward are already more compassionate and hold a better view of more marginalized groups, even those who have broken the laws of society.

To further appreciate the motivations and experiences of prison volunteers, the mean scores of the VSI and VFI were calculated (Table 3). The underlying function of values scored highest among the prison volunteers, showing that they were most motivated by their desire to express values and help others. The prison volunteers also reported satisfaction in terms of personal gain and relationship with peers from their volunteering experiences. The volunteering motivations of career and social enhancement and feelings of guilt scored lowest.

Turning our attention to whether volunteering experiences, namely length of time volunteering with prisoners and satisfaction with the volunteering experience and the underlying functions of the VFI, would impact attitudes toward prisoners, ordinary least square (OLS) regression was performed for the prison volunteers group. Bivariate analyses were first conducted to determine which variables were suitable for insertion into the regression model. Neither education level nor marital status showed any significant between-group differences with respect to attitudes toward prisoners, and were subsequently excluded. All of the other independent variables ${ }^{1}$ —age, time serving prisoners (measured in months), religion, and results from the VSI and VFI - were included as independent variables, with the score of the ATP scale acting as the dependent variable. The results are presented in Table 4.

Only one significant result for underlying function for volunteer motivation was found, namely values. The motivation for prison volunteers to express humanitarian values and help others correlated significantly with the positive attitude that prisoners are capable of positive change $(p<0.01)$. Other dimensions of the VFI and VSI showed no statistically significant relationships with ATP. Likewise, age, religion, and the length of time spent volunteering in prisons displayed no significant correlations with ATP.

\section{Discussion and Conclusion}

Correctional institutions are increasingly employing the services of volunteers to assist in a wide range of rehabilitation activities for inmates. This trend is occurring not just in Western

\footnotetext{
${ }^{1}$ The variable gender was excluded from the multivariate analysis because of the disproportionate ratio between males and females.
} 
Table 4 Regression of attitudes toward prisoners by prison volunteers $(N=54)$

$* * p<0.01$

\begin{tabular}{lrl}
\hline Predictor & \multicolumn{1}{c}{$\mathrm{B}$} & $\mathrm{SE}$ \\
\hline Age & -0.01 & 0.01 \\
Time serving offenders (in months) & 0.01 & 0.01 \\
Religion (1=Christianity) & -0.04 & 0.14 \\
VSI & & \\
Relationship with organization & 0.01 & 0.07 \\
Personal gain & -0.07 & 0.13 \\
Relationship with peers & 0.12 & 0.08 \\
VFI & & \\
Values & 0.20 & $0.07^{* *}$ \\
Understanding & 0.04 & 0.09 \\
Enhancement & -0.11 & 0.07 \\
Career & 0.03 & 0.06 \\
Social & -0.07 & 0.05 \\
Protective & -0.07 & 0.06 \\
Adjusted $R^{2}$ & 0.23 & \\
\hline
\end{tabular}

settings but also in the Hong Kong Chinese context. Yet, very few studies have examined prison volunteers, and those that have, have not measured prison volunteers' attitudes toward prisoners. The present study examined three groups' attitudes toward prisoners: prison volunteers, non-prison volunteers, and non-volunteers. While it would be expected that prison volunteers would exhibit the most positive attitudes toward prisoners, our findings reveal that volunteers in general, regardless of whether they work with prisoners or not, also display more positive attitudes toward prisoners compared to non-volunteers.

To further determine whether volunteering experiences or volunteer motivations have any correlations with attitudes toward prisoners, regression analyses were performed with the prison volunteer group. The only independent variable that displayed any significance was the motivational function of values. It is telling that a desire to help others and to express humanitarian values correlated with the belief that prisoners can be positively changed. This lends support to the notion that prison volunteers are driven by wanting to assist prisoners and believe that their volunteer work can indeed create change in the lives of inmates. This differs somewhat from past studies that showed that prison volunteers are simply content with sharing their beliefs with inmates, without any goal of converting them to accept their religious faith (Kerley et al. 2009). This also raises the concern that prison volunteers could take this motivation to express their own values and engage in unwarranted religious proselytizing, especially since most of the prison volunteers in our sample reported that they were Christians and were motivated to volunteer mostly by the opportunity to express their values.

Correctional services should take heed of this as there is now a greater emphasis on collaborations between correctional institutions and NGOs that can mobilize large numbers of volunteers. Ethical dilemmas may arise if volunteers pursue proselytizing without the consent of their clienteles, especially since a large number of NGOs are promoting faithbased programs as well as secular programs inside prisons (Chui and Cheng 2011). The past literature has revealed that many volunteers receive little training prior to commencing their volunteer work; they need to be given strict guidelines to avoid ethical issues. Future studies should examine the training (or lack thereof) that prison volunteers are given before they come into contact with inmates. In addition, the activities that prison volunteers engage in 
require greater inspection. From past studies, we know that prison volunteers engage in the sharing of their religious beliefs, preaching and teaching spiritual texts in small group or even one-to-one settings (Chui and Cheng 2011; Tewksbury and Collins 2005). What these interactions entail remains largely hidden. It should be noted that the authors are not objecting to volunteers having discussions on spiritual issues with inmates, as we recognize that spirituality/ religion may be an important element in helping inmates to desist from crime and to cope with prison conditions. We do feel, however, that the work of prison volunteers should be performed in an ethical manner that is respectful to both the correctional institution and prisoners.

While this study is the first to measure volunteer experiences with attitudes toward prisoners, its limitations must be acknowledged. The results indicate that, in our sample, the volunteers, including the prison volunteers, demonstrated more positive attitudes toward prisoners than non-volunteers. These results must be interpreted with caution. Since this was not a longitudinal study, it is difficult to ascertain whether the prison volunteers were more positive toward prisoners because they volunteered with prisoners or whether they viewed prisoners in a more kindly light and thus decided to do volunteer work with them. Future studies should measure the attitudes of prison volunteers toward prisoners prior to the commencement of their voluntary work and again after they have done their volunteering, and compare the results.

Another limitation to this study is that it utilized broad measurements to gauge volunteer satisfaction and motivation. Although expressing values correlated strongly with a belief that prisoners can change, there is no direct evidence of prison volunteers being motivated by religious purposes or participating in any unwelcome religious proselytizing. What this study does is add to the scarce literature on prison volunteers, a group that is taking on an increasingly larger role in the rehabilitation and reintegration of inmates. Guidelines outlined in past scholarship for social workers are applicable to prison volunteers as well. Prison volunteers should be candid about their roles up front and inform inmates of what they intend to achieve during their visits. They should also avoid playing the multiple roles of providing services such as training courses and pursuing religious conversations at the same time. Again, if the role of the volunteer is to discuss issues of spirituality, this should be made known to inmates up front. Better guidelines for prison volunteers will help not only to prevent ethical dilemmas but will also avoid confrontations with inmates, which can only assist in their rehabilitation.

Open Access This article is distributed under the terms of the Creative Commons Attribution License which permits any use, distribution, and reproduction in any medium, provided the original author(s) and the source are credited.

\section{References}

Allport, G. W. (1954). The Nature of Prejudice. Reading: Addison-Wesley.

Canda, E., Nakashima, M., \& Furman, L. D. (2004). Ethical considerations about spirituality in social work: Insights from a national qualitative survey. Families in Society, 85(1), 27-35.

Chui, W. H. (2005). Detention center in Hong Kong: A young offender's narrative. Journal of Offender Rehabilitation, 41(1), 67-84.

Chui, W. H., \& Cheng, K. K. (2011). Self-perceived role and function of Christian prison chaplains and Buddhist volunteers in Hong Kong prisons. International Journal of Offender Therapy and Comparative Criminology. doi:10.1177/0306624X11432128.

Clary, E. G., Snyder, M., Ridge, R. D., Copeland, J., Stukas, A. A., Haugen, J., et al. (1998). Understanding and assessing the motivations of volunteers: A functional approach. Journal of Personality and Social Psychology, 14(6), 1516-1530. 
Galindo-Kuhn, R., \& Guzley, R. M. (2001). The volunteer satisfaction index: construct definition, measurement, development, and validation. Journal of Social Service Research, 28(1), 45-68.

Gilbert, M. C. (2000). Spirituality in social work groups: practitioners speak out. Social Work With Groups, 22 (4), 67-84.

Gilligan, P., \& Furness, S. (2006). The role of religion and spirituality in social work practice: views and experiences of social workers and students. British Journal of Social Work, 36(4), 617-637.

Henry, J. S., \& Jacobs, J. B. (2007). Ban the box to promote ex-offender employment. Criminology and Public Policy, 6(4), 755-762.

Hodge, D. R. (2005). Spiritual ecograms: a new assessment instrument for identifying clients' strengths in space and across time. Families in Society, 86(2), 287-296.

Hong Kong Correctional Services (2010a). Hong Kong Correctional Services Review 2010. Retrieved from http://www.csd.gov.hk/view/2010/ebook/csd_sc.html. Accessed March 2, 2012.

Hong Kong Correctional Services (2010b) About us. Retrieved from http://www.csd.gov.hk/english/abt/ abt.html. Accessed March 2, 2012.

Hong Kong Correctional Services (2010c) CSD Rehabilitation Volunteer Group. Retrieved from http:// www.csd.gov.hk/english/reh/reh_over/reh_over_vg.html. Accessed March 3, 2012.

Horn, R., \& Hollin, C. (1997). Police beliefs about women who offend. Legal and Criminological Psychology, 2(2), 193-204.

Human Rights Watch and the Hong Kong Human Rights Monitor (1997) Hong Kong: Prison conditions in 1997. Retrieved from http://hkhrm.org.hk/english/reports/prison.html. Accessed February 12, 2012.

Jayasinghe, S. (2007). Faith-based NGOs and healthcare in poor countries: a preliminary exploration of ethical issues. Journal of Medical Ethics, 33(11), 623-626.

Kerce, E. W., Magnusson, P., Rudolph, A. (1994). The attitudes of navy corrections staff members: What they think about confinees and their jobs. Navy Personnel Research and Development Center.

Kerley, K. R., Matthews, T. L., \& Shoemaker, J. (2009). A simple plan, a simple faith: chaplains and lay ministers in Mississippi prisons. Review of Religious Research, 51(1), 87-103.

Kjelsberg, E., Skoglund, T. H., \& Rustad, A. B. (2007). Attitudes towards prisoners, as reported by prison inmates, prison employees and college students. BMC Public Health, 7, 71-79.

Laidler, K. J. (2009). Correctional services department. In M. S. Gaylord, D. Gittings, \& H. Traver (Eds.), Introduction to Crime, Law and Justice in Hong Kong (pp. 185-204). Hong Kong: Hong Kong University Press.

Maxwell, P., \& Mallon, D. (1997). Discrimination against ex-offenders. The Howard Journal, 36(4), 352-366.

McRoberts, O. M. (2002). Religion, reform, community: examining the idea of church-based prisoner reentry. Retrieved from http://www.urban.org/UploadedPDF/410802_Religion.pdf. Accessed June 1, 2012.

Melvin, K. B., Grambling, L. K., \& Gardner, W. M. (1985). A scale to measure attitudes towards prisoners. Criminal Justice and Behavior, 12(2), 241-253.

Murphy, E., \& Brown, J. (2000). Exploring gender role identity, value orientation of occupation and sex of respondent in influencing attitudes towards male and female offenders. Legal and Criminological Psychology, 5(2), 285-290.

Na, E. Y., \& Lofius, E. F. (1998). Attitudes toward law and prisoners, conservative authoritarianism, attribution, and internal-external locus of control: Korean and American law students and undergraduates. Journal of Cross-Cultural Psychology, 29(5), 595-615.

Ortet-Fabregat, G., Pérez, J., \& Lewis, R. (1993). Measuring attitudes toward prisoners: a psychometric assessment. Criminal Justice and Behavior, 20(2), 190-198.

Pettigrew, T. F., \& Tropp, L. (2000). Does intergroup contact reduce prejudice? Recent meta-analytic findings. In S. Oskamp (Ed.), Reducing Prejudice and Discrimination: Social Psychological Perspectives (pp. 93114). Mahwah: Erlbaum.

Potuto, J. R. (1980). A model proposal to avoid ex-offender employment discrimination. Ohio State Law Journal, 41(1), 78-106.

Sheridan, M. J., Wilmer, C. M., \& Atcheson, L. (1994). Inclusion of content on religion and spirituality in the social work curriculum: a study of faculty views. Journal of Social Work Education, 30 (3), 363-376.

Sheriff, M. (1966). In common predicament: social psychology of intergroup conflict and cooperation. Boston: Houghton-Mifflin.

Sherr, M. E., Singletary, J. E., \& Rogers, R. K. (2009). Innovative service or proselytizing: exploring when services delivery becomes a platform for unwanted religious persuasion. Social Work, 54(2), 157-165.

Spano, R. (2007). What is sacred when personal and professional values collide? Journal of Social Work Values and Ethics, 4(3). Retrieved from http://www.socialworker.com/jswve/content/view/4/27/. Accessed June 2, 2012.

Sundt, J. L., \& Cullen, F. T. (1998). The role of the contemporary prison chaplain. The Prison Journal, 78(3), 271-298.

Sundt, J. L., Dammer, H. R., \& Cullen, F. T. (2002). The role of the prison chaplain in rehabilitation. Journal of Offender Rehabilitation, 35(3-4), 59-86. 
Tewksbury, R., \& Collins, S. C. (2005). Prison chapel volunteers. Federal Probation, 69(1), 26-30.

Tewksbury, R., \& Dabney, D. (2004). Prison volunteers. Journal of Offender Rehabilitation, 40(1-2), $173-183$.

Uggen, C., Manza, J., \& Behrens, A. (2004). Less than the average citizen: stigma, role transition, and the civic reintegration of convicted felons. In S. Maruna \& R. Immarigeon (Eds.), After crime and punishment: pathways to offender reintegration (pp. 258-290). Devon: Willan.

Wong, L. P., Chui, W. H., \& Kwok, Y. Y. (2011). The volunteer satisfaction index: a validation study in the Chinese cultural context. Social Indicators Research, 104, 19-32.

Worthington, E. L., Kurusu, T. A., McCullough, M. E., \& Sandage, S. J. (1996). Empirical research on religion and psychotherapeutic processes and outcomes: a 10-year review and research prospectus. Psychological Bulletin, 119(3), 448-487.

Wu, J., Lo, T. W., \& Liu, E. S. C. (2009). Psychometric properties of the volunteer functions inventory with Chinese students. Journal of Community Psychology, 37(6), 769-780. 